\title{
Does Market Welcome the International Convergence of Fair Value Standard in China?
}

\author{
Dehong Wang ${ }^{1}$, Jianbo Song ${ }^{2}$, Yue Zhang ${ }^{1}$ \\ ${ }^{1}$ International Business School, Beijing Foreign Studies University, Beijing, China \\ ${ }^{2}$ School of Business, Renmin University of China, Beijing, China \\ Correspondence: Jianbo Song, School of Business, Renmin University of China, Beijing, China.
}

Received: February 3, 2017

Accepted: February 27, 2017

Available online: March 1, 2017

doi:10.11114/afa.v3i2.2192

URL: https://doi.org/10.11114/afa.v3i2.2192

\begin{abstract}
This paper studies the international convergence of fair value measurement standard and examines market reactions towards the emergence of the standard in China. Through comparing the fair value measurement standard between IFRS 13 and newest Chinese accounting standard CAS 39, we find that CAS 39 is on the way of international convergence towards IFRS 13. Through examining market reactions to CAS 39, we find that market has significantly positive reactions to the draft version exposure, official announcement, and enforcement of CAS 39. Moreover, we find that investors have different attitudes to the applications of CAS 39 in financial and non-financial industries. Investors consistently support CAS 39 in non-financial industries. However, in financial industries, investors react positively in the draft version exposure of CAS 39, but negatively in the official announcement and enforcement of CAS 39. We believe that investors worry about the application of CAS 39 in Chinese financial industries.
\end{abstract}

Keywords: market reaction, international convergence, fair value measurement, IFRS

\section{Introduction}

As many countries claimed adopting or converging with IFRS ${ }^{1}$, fair value measurement plays an increasingly important role in accounting. However, China takes a long history to accept and adopt the fair value measurement in its accounting standard system. Nearly a decade after China met the concept "fair value", fair value and its measurement became part of Chinese accounting standards in 2006 for the first time. Nevertheless, its application and standards in the 2006 edition of $\mathrm{CAS}^{2}$ are scattered and confined to certain specific areas. After publishing "The Roadmap of Sustained International Convergence of Chinese Accounting Standards towards International Financial Reporting Standards" in 2010, on January 26, 2014, Chinese Ministry of Finance (the maker of accounting standards in China) announced a new fair value accounting standards, CAS 39, which was in force on July 1, 2014 ${ }^{3}$. It was the first time that the fair value measurement becomes a standalone standard in Chinese accounting system.

Making a newer standard for fair value measurement - CAS 39 stands for accounting changes not only for standard setters and supervisors but also for investors and enterprise managers. Therefore, the purpose of this study is twofold. The main purpose is to find out consistency and differences between CAS 39 and IFRS 13 through detailed comparison. The comparison will assist with betterment and improvement of Chinese Accounting Standards in the way of international convergence with IFRS. Second, since it is difficult to test market reactions to the convergence directly, we examine stock market responses in China to a series of events of introduction progress of CAS 39. The examination of

${ }^{1}$ IFRS: International Financial Reporting Standards.

${ }^{2}$ CAS: Chinese Accounting Standards. The 2006 edition of CAS was issued on February 15, 2006.

${ }^{3}$ Accounting Department, Chinese Ministry of Finance. Enterprise Accounting Standard No.39 - Fair Value Measurement. January 26, 2014.

These authors contributed equally to this work and should be considered as co-first authors.

These authors thank for the funding support from the Renmin University of China Science Research Foundation, Project No. 15XNI010. 
market reactions should reveal insights into investors' viewpoint towards the process of international convergence of fair value measurement standard. Through examination, we find that CAS 39 is generally welcome in the Chinese stock market. However, investors' reactions are different in financial and non-financial industries in the emergence of CAS 39. Investors consistently welcome the emergence of CAS 39 in non-financial industries. As for the application of CAS 39 in financial industries, investors' attitudes seem contradictory.

This paper consists of six sections: Section 2 reviews the relevant literatures and compares CAS 39 with IFRS 13. We find out the international convergence of fair value measurement in China towards IFRS. Section 3 decomposes the topic of this study into detailed research questions, and makes research design. Section 4 describes sample data and descriptive statistics. Section 5 analyses empirical results. Section 6 further discusses market's attitudes on fair value measurement in China, limitations of this research, and concludes this paper.

\section{The International Convergence of Fair Value Standards in China}

Fair value is now widely used in many diverse areas as financial derivatives. Its application has swept the globe. However, researching on fair value application in China has been rather slow. China first introduced fair value measurement in June 1998 in debt reconstruction and non-monetary assets exchange standards. Because of the ambiguity of the standards at that time, some listed companies manipulated fair value and made accounting frauds. Thus, Chinese Ministry of Finance (the maker of CAS) soon cancelled the application on fair value in debt reconstruction, non-monetary assets' exchange, and investment standards, and replaced the measurement of these assets and liabilities back to historical cost or book value.

After years' argument and discussion, China issued a new CAS in 2006 (the 2006 edition of CAS) in which defined fair value as one of the accounting measurement attributes. The reintroduction of fair value became a breakthrough in the 2006 edition of CAS. However, fair value standards in the 2006 edition of CAS are dispersed in various clauses other than as a separate accounting standard. In order to aggrandize unified criteria on fair value measurement and keep up with IFRS, in 2012, China issued a draft version of new accounting standards on fair value measurement to test market reactions and collect comments from investors and company management. Eventually, in 2014, China issued another new standard on fair value measurement, namely, CAS 39-Fair Value Measurement.

\subsection{Features of CAS 39}

\subsubsection{Definition of Fair Value}

The 2006 edition of CAS defined fair value as 'the amount of money in a voluntary asset exchange or debt repayment by a fair transaction between both parties who are familiar with the condition.' However, the definition does not have specific metrology object and lack of effectiveness in operation ( $\mathrm{Lv}$ and $\mathrm{Li}, 2014)$. CAS 39 redefines fair value as 'the price that would be received to sell an asset or would be paid to transfer a liability in an orderly transaction between market participants at a measurement date ${ }^{4}$. The definition is approximately similar to or the same as IFRS 13, Fair Value Measurement. The redefinition of fair value in CAS 39 provides a clearer and more unified guidance for fair value measurement in China.

Table 2.1. General Framework of CAS 39

\begin{tabular}{lll}
\hline Chapter 1 & General Provisions & Clause 1-5 \\
Chapter 2 & Related Assets or Liabilities & Clause 6-7 \\
Chapter 3 & Orderly Transactions and Market & Clause 8-13 \\
Chapter 4 & Market Participants & Clause 14-15 \\
Chapter 5 & Fair Value Initial Measurement & Clause 16-17 \\
Chapter 6 & Valuation Techniques & Clause 18-23 \\
Chapter 7 & Fair Value Hierarchy & Clause 24-28 \\
Chapter 8 & Non-financial Assets Fair Value Measurement & Clause 29-32 \\
Chapter 9 & Liabilities and Enterprise's Own Equity Instrument Fair Value Measurement & Clause 33-37 \\
Chapter 10 & Fair Value Measurement of Financial Assets and Liabilities Whose Market Risk or Credit Risk Can be & Clause 38-41 \\
& Offset & Clause 42-50 \\
Chapter 11 & Fair Value Disclosure & Clause 51-52 \\
Chapter 12 & Cohesion Provisions & Clause 53 \\
Chapter 13 & Supplementary Provisions & Capter \\
\hline
\end{tabular}

Note: This table lists title and clause number of each Chapter in CAS 39. The titles reveal the main contents in the chapter.

\footnotetext{
${ }^{4}$ Accounting Department, Chinese Ministry of Finance. Enterprise Accounting Standard No.39 - Fair Value Measurement. January 26, 2014.
} 


\subsubsection{Fair Value Measurement Framework}

CAS 39 sets out a single framework for fair value measurement and provides comprehensive guidance on how to measure fair value. It includes 13 chapters and 53 clauses altogether (see Table 2.1).

\subsubsection{Fair Value Hierarchy}

Both IFRS 13 and CAS 39 categorize valuation inputs into a three-level fair value hierarchy. The fair value hierarchy gives the highest priority to quoted prices in active markets for identical assets (Level 1 inputs) and the lowest priority to unobservable inputs (Level 3 inputs). These inputs are assumptions that market participants use in pricing assets or liabilities. However, the assumptions used in pricing may or may not be accessible from market data in some circumstances.

Level 1 inputs are unadjusted prices in active markets for identical assets that the firm can access at the measurement date. It is mandatory to use unadjusted prices in active markets in that information asymmetry between investors and company management is very low with Level 1 inputs. Level 2 inputs are directly or indirectly observable inputs for an asset. Level 2 inputs should have excellent reliability as they are corroborated by observable market data. Level 3 inputs are unobservable inputs for an asset's fair value measurement. Unobservable inputs are inputs for which market data are not available. Therefore, it is necessary to develop these inputs based on the best information available about the assumptions that market participants would use when pricing the asset. Level 3 inputs are subject to the highest degree of information asymmetry between investors and company management.

Table 2.2. Comparison of CAS 39 (Chapter 1-4) and IFRS 13

\begin{tabular}{|c|c|c|}
\hline CAS 39 & IFRS 13 & Comparison \\
\hline Chapter 1 General Provisions & Objective & \\
\hline Clause 1 Legal basis & Clause $1 / 2 / 3 / 4$ & CAS focuses on legal basis while IFRS on objectives \\
\hline Clause 2 Definition & Clause $9 / 24$ & $\begin{array}{l}\text { Basically consistent. IFRS reinforces that fair value price is } \\
\text { based on the main market, no matter it is observable or } \\
\text { estimated }\end{array}$ \\
\hline Clause 3 Suitable Scope & Clause 5/7 & Consistent \\
\hline Clause 4 Suitable Accounts & Clause 6 & Consistent \\
\hline Clause 5 Unsuitable situations & Clause $7 / 8$ & Consistent \\
\hline Chapter 2 Related Asset or Liability & $\begin{array}{l}\text { The Asset or } \\
\text { Liability }\end{array}$ & \\
\hline Clause 6 Characteristics & Clause 11/12 & Basically consistent. IFRS is in more details \\
\hline Clause 7 Unit of Account & Clause 13/14 & Basically consistent. IFRS is in more details \\
\hline Chapter 3 Orderly Transactions and Market & The Transaction & \\
\hline Clause 8 Orderly Transaction & Clause 15 & Consistent \\
\hline Clause 9 Transaction Costs & $\begin{array}{l}\text { Clause } 16, \\
\text { Appendix A }\end{array}$ & Consistent \\
\hline Clause 10 Main Market & Clause 17 & Consistent \\
\hline $\begin{array}{l}\text { Clause } 11 \text { Main Market and Measurement } \\
\text { Date }\end{array}$ & Clause 19 & Consistent \\
\hline Clause 12 When No Main Market Exists & $\begin{array}{l}\text { Clause } \\
18 / 20 / 25 / 26\end{array}$ & $\begin{array}{l}\text { Basically consistent. IFRS emphasize that fair value pricing } \\
\text { does not need physically sell/transfer a specific asset or liability }\end{array}$ \\
\hline Clause 13 Price Unobservable & Clause 21 & Consistent \\
\hline Chapter 4 Market Participants & $\begin{array}{l}\text { Market } \\
\text { Participant }\end{array}$ & \\
\hline $\begin{array}{l}\text { Clause } 14 \text { Assumption of economic best } \\
\text { interest, definition of market participants }\end{array}$ & $\begin{array}{l}\text { Clause } 22, \\
\text { Appendix A }\end{array}$ & Consistent \\
\hline $\begin{array}{l}\text { Clause } 15 \text { Identification of market } \\
\text { participants }\end{array}$ & Clause 23 & Consistent \\
\hline
\end{tabular}

Note: This table compares the contents in each clause in CAS 39 from Chapter 1 to 4 with correspondent contents in IFRS 13. The third column in the table shows specific differences or consistency between CAS 39 and IFRS 13.

\subsection{Comparison between CAS 39 and IFRS 13}

\subsubsection{General Framework}

IFRS 13 has four main parts (objectives, scope, measurement, and disclosure), including 99 paragraphs. IFRS 13 also includes four appendices, including defined terms, application guidance, effective date and transition, and amendments to other IFRSs (IFRS, 2011). Although the outline of CAS 39 is very similar to IFRS 13, there are slight differences between them. In order to match CAS 39 with IFRS 13 in clearer tabular manner, we split the comparative table into three smaller tables. Table 2.2 compares Chapter $1-4$ of CAS 39 and IFRS 13 rule by rule. Table 2.3a/b compare Chapter 5-8 of CAS 39 and IFRS 13 rule by rule. Table $2.4 \mathrm{a} / \mathrm{b}$ compare Chapter 9-13 of CAS 39 and IFRS 13 rule by rule. 
In Chapter 1-4 of CAS 39, there are fifteen clauses. Among these clauses, 10 clauses (66.67\%) are consistent with IFRS 13; 4 clauses (26.67\%) are basically consistent with IFRS 13; 14 clauses (93.33\%) are either consistent or basically consistent with IFRS 13.9 clauses in CAS 39 (60\%) are corresponding to more than one clause in IFRS 13. Therefore, IFRS 13 usually has more details in terms of a number of clauses.

Table 2.3a. Comparison of CAS 39 (Chapter 5-6) and IFRS 13

\begin{tabular}{|c|c|c|}
\hline CAS 39 & IFRS 13 & Comparison \\
\hline $\begin{array}{l}\text { Chapter } 5 \text { Fair Value Initial } \\
\text { Measurement }\end{array}$ & $\begin{array}{l}\text { Fair Value at Initial } \\
\text { Recognition }\end{array}$ & \\
\hline $\begin{array}{l}\text { Clause } 16 \text { Judgment of initial } \\
\text { measurement }\end{array}$ & Clause 57 & Basically consistent. IFRS is in more details \\
\hline Clause 17 Gain or loss & Clause 60 & Consistent \\
\hline $\begin{array}{lll}\text { Chapter } & 6 & \text { Valuation } \\
\text { Techniques } & & \end{array}$ & Valuation Techniques & \\
\hline Clause 18 Valuation Methods & $\begin{array}{l}\text { Clause 61/62/63, } \\
\text { Appendix A }\end{array}$ & $\begin{array}{l}\text { Basically consistent. IFRS has examples on single and multiple valuation } \\
\text { methods }\end{array}$ \\
\hline $\begin{array}{l}\text { Clause } 19 \text { Inputs to Valuation } \\
\text { Techniques }\end{array}$ & $\begin{array}{l}\text { Clause } \\
\text { Appendix A }\end{array}$ & $\begin{array}{l}\text { Basically consistent. CAS emphasizes unobservable inputs only when } \\
\text { observable inputs are not available. IFRS has examples }\end{array}$ \\
\hline $\begin{array}{l}\text { Clause } 20 \text { Adjustment on } \\
\text { valuation }\end{array}$ & Clause 64 & $\begin{array}{l}\text { Basically consistent. IFRS emphasizes that adjustment or correction on } \\
\text { valuation is necessary }\end{array}$ \\
\hline $\begin{array}{l}\text { Clause } 21 \text { Situation of } \\
\text { Changes }\end{array}$ & Clause 65 & Consistent \\
\hline $\begin{array}{l}\text { Clause } 22 \text { Premium and } \\
\text { Discount }\end{array}$ & Clause 69 & $\begin{array}{l}\text { Basically consistent. IFRS emphasizes that it should not be adjusted for } \\
\text { prices in active market }\end{array}$ \\
\hline $\begin{array}{l}\text { Clause } 23 \text { Bid and Asked } \\
\text { Prices }\end{array}$ & Clause $70 / 71$ & Consistent \\
\hline
\end{tabular}

Note: This table compares the difference and consistency in detail between CAS 39 and IFRS 13 in terms of Chapter 5 and 6 of CAS 39 .

Of 17 clauses in Chapter 5-8 of CAS 39, 11 (6) clauses are consistent or basically consistent with IFRS 13. In other words, these chapters of CAS 39 100\% are either consistent or basically consistent with IFRS 13. However, 10 clauses in these chapters of CAS 39 are corresponding to more than one IFRS clause. Therefore, these chapters of CAS 39 are not as detailed as IFRS 13 in the perspective of a number of clauses.

Among the 21 clauses in Chapter 9-13 of CAS 39, 20 clauses (95.23\%) are consistent with IFRS, and only 1 clause is basically consistent with IFRS. Compared to these 21 clauses, IFRS uses 35 clauses. Therefore, IFRS is in more details in terms of a number of clauses.

In summary, among 53 clauses of CAS 39, $41(77.36 \%)$ are consistent with IFRS and $11(20.75 \%)$ are basically consistent with IFRS. In other words, $98.11 \%$ clauses in CAS 39 are either consistent or basically consistent with IFRS 13. Therefore, fair value measurement in China Accounting Standards is in close convergence with IFRS. Furthermore, there are 53 clauses in CAS 39 while 103 clauses (including Appendix A and C1-C3) in IFRS 13. Therefore, in terms of a number of clauses, IFRS 13 has more details than CAS 39.

Besides the differences in consistency and explanatory details between CAS 39 and IFRS 13, there are other differences in the integrity of fair value framework, including definition approach and application on fair value. 
Table 2.3b. Comparison of CAS 39 (Chapter 7-8) and IFRS 13

\begin{tabular}{|c|c|c|}
\hline CAS 39 & IFRS 13 & Comparison \\
\hline $\begin{array}{llll}\text { Chapter } & 7 & \text { Fair } & \text { Value } \\
\text { Hierarchy } & & & \end{array}$ & Fair Value Hierarchy & \\
\hline $\begin{array}{l}\text { Clause } 24 \text { Inputs of three } \\
\text { levels }\end{array}$ & $\begin{array}{l}\text { Clause } \\
\text { Appendix A }\end{array}$ & Consistent. IFRS is in more details \\
\hline Clause 25 First level input & Clause 76/77/78/79/80 & $\begin{array}{l}\text { Consistent. IFRS is in more details in } 76 / 77 / 79 \text {; IFRS emphasizes the } \\
\text { situation in multiple active markets in } 78 \text {; IFRS makes it clear the factor } \\
\text { of market capacity in } 80\end{array}$ \\
\hline Clause 26 Second level input & $\begin{array}{l}\text { Clause } \\
75 / 81 / 82 / 83 / 84 / 85\end{array}$ & Consistent. But IFRS specifies in more details \\
\hline Clause 27 Third level & Clause $86 / 87 / 88$ & Consistent. But IFRS has more details \\
\hline Clause 28 Unobservable input & Clause $89 / 90$ & Consistent \\
\hline $\begin{array}{lll}\text { Chapter } & 8 & \text { Non-financial }\end{array}$ & Application & \\
\hline $\begin{array}{l}\text { Assets Fair } \quad \text { Value } \\
\text { Measurement }\end{array}$ & Non-financial Assets & \\
\hline $\begin{array}{l}\text { Clause } 29 \text { Capability for best } \\
\text { use }\end{array}$ & Clause 27, Appendix A & $\begin{array}{l}\text { Basically consistent. CAS simplifies "best efficiency" and "best use" } \\
\text { into "best use" }\end{array}$ \\
\hline $\begin{array}{l}\text { Clause } 30 \text { Feasibility of best } \\
\text { use }\end{array}$ & Clause 28 & Consistent \\
\hline $\begin{array}{l}\text { Clause } 31 \text { Best use from } \\
\text { market participants }\end{array}$ & Clause 29 & Consistent \\
\hline $\begin{array}{l}\text { Clause } 32 \text { Premise to } \\
\text { valuation }\end{array}$ & Clause $31 / 32 / 33$ & Consistent \\
\hline
\end{tabular}

Note: This table compares clauses in Chapter 7 and 8 in CAS 39 with clauses in IFRS 13.

Table 2.4a. Comparison of CAS 39 (Chapter 9-10) and IFRS 13

\begin{tabular}{|c|c|c|}
\hline CAS 39 & IFRS 13 & Comparison \\
\hline Chapter 9 Liabilities and Enterprise's Own Equity & Application to Liabilities and an Entity's Own Equity & \\
\hline Instrument Fair Value Measurement & Instruments & \\
\hline Clause 33 Liabilities and equity instruments & Clause 34 & Consistent \\
\hline $\begin{array}{l}\text { Clause } 34 \text { Principles to liabilities and equity } \\
\text { instruments }\end{array}$ & Clause 35/36/37/38/39/40/41 & $\begin{array}{l}\text { Consistent. But IFRS } \\
\text { is in much more details }\end{array}$ \\
\hline Clause 35 Risk of default & Clause $42 / 43 / 44$ & $\begin{array}{l}\text { Consistent. But IFRS } \\
\text { is in much more details }\end{array}$ \\
\hline Clause 36 Restricted factors & Clause $45 / 46$ & $\begin{array}{l}\text { Consistent. IFRS also } \\
\text { provides examples }\end{array}$ \\
\hline Clause 37 Financial liabilities & Clause 47 & Consistent \\
\hline Chapter 10 Fair Value Measurement of Financial & Applications to Financial Assets and Financial & \\
\hline $\begin{array}{l}\text { Assets and Liabilities Whose Market Risk or } \\
\text { Credit Risk Can be Offset }\end{array}$ & $\begin{array}{l}\text { Liabilities Whose Market Risk or Credit Risk has } \\
\text { Offsetting Positions }\end{array}$ & \\
\hline Clause 38 Financial assets and financial liabilities & Clause $48 / 50 / 52$ & Consistent \\
\hline $\begin{array}{l}\text { Clause } 39 \text { Conditions for financial assets and } \\
\text { financial liabilities }\end{array}$ & Clause 49 & Consistent \\
\hline $\begin{array}{l}\text { Clause } 40 \text { Market risk and term for financial } \\
\text { assets and liabilities }\end{array}$ & Clause 53/54/55/56 & $\begin{array}{l}\text { Consistent. But IFRS } \\
\text { has much more details }\end{array}$ \\
\hline Clause 41 Accounting policies & Clause 51 & Consistent \\
\hline
\end{tabular}

Note: This table shows the comparison between IFRS 13 and CAS 39 in Chapter 9 and 10, namely, from Clause 33 to 41 in CAS 39. 
Table 2.4b. Comparison of CAS 39 (Chapter 11-13) and IFRS 13

\begin{tabular}{|c|c|c|}
\hline CAS 39 & IFRS 13 & Comparison \\
\hline Chapter 11 Fair Value Disclosure & Disclosure & \\
\hline Clause 42 Grouping assets and liabilities & Clause 94 & Consistent \\
\hline Clause 43 Recurring and non-recurring & $\begin{array}{l}\text { Clause } \\
91 / 92\end{array}$ & $\begin{array}{l}\text { Basically consistent. IFRS emphasizes the factors that should be } \\
\text { considered in realizing the objectives of disclosure }\end{array}$ \\
\hline Clause 44/45 Information that needs disclosure & Clause 93 & $\begin{array}{l}\text { Consistent. But IFRS requires separate disclosure on recurring } \\
\text { and non-recurring fair value measurement }\end{array}$ \\
\hline $\begin{array}{l}\text { Clause } 46 \text { Time point change of fair value } \\
\text { measurement }\end{array}$ & Clause 95 & Consistent. IFRS also provides examples \\
\hline Clause 47 Exceptional accounting policies & Clause 96 & Consistent \\
\hline $\begin{array}{l}\text { Clause } 48 \text { Assets and liabilities not measured in } \\
\text { fair value but disclosed in fair value }\end{array}$ & Clause 97 & Consistent \\
\hline $\begin{array}{l}\text { Clause } 49 \text { Liabilities with inseparable third-party } \\
\text { credit enhancement }\end{array}$ & Clause 98 & Consistent \\
\hline Clause 50 Tabular format & Clause 99 & Consistent \\
\hline Chapter 12 Cohesion Provisions & Transition & \\
\hline Clause 51 Retrospective adjustment & $\mathrm{C} 2$ & Consistent \\
\hline Clause 52 Comparative financial statements & $\mathrm{C} 3$ & Consistent \\
\hline Chapter 13 Supplementary Provisions & $\begin{array}{l}\text { Effective } \\
\text { Date }\end{array}$ & \\
\hline Clause 53 Effective date & $\mathrm{C} 1$ & Consistent \\
\hline
\end{tabular}

Note: This table shows the contents of last three chapters in CAS 39 (Chapter 11 to 13) and compares them with correspondent details in IFRS 13.

\subsubsection{Definition Approach}

IFRS 13 defines fair value price as an exit price while CAS 39 does not have such an explicit mandate. Considering non-financial assets, IFRS applies the principle "Highest and best use for non-financial assets.". However, there is not any such principle in CAS 39. In valuation techniques, although CAS 39 and IFRS 13 both include the market approach, the cost approach, and the income approach, IFRS discusses "valuation techniques" and "inputs of valuation techniques" in separate parts while CAS 39 does not separate them clearly. IFRS discusses these three levels of fair value separately and in detail while CAS 39 only lists these three-level outputs of fair value measurement. Therefore, compared to CAS 39, IFRS 13 has more integration in terms of fair value framework.

\subsubsection{Application on Fair Value}

Both CAS 39 and IFRS 13 integrate fair value measurement in four parts-financial assets and liabilities, non-financial assets and liabilities, asset impairment, income, and equity. However, CAS 39 still follows IFRS No.9 that classifies financial assets into four types: financial assets that adopt fair value and affect profit and loss by their changes in fair value; held-to-maturity investment; loans and account receivables; available-for-sale financial assets. IFRS 13 simplifies financial assets into two types: fair value and amortized cost. It is still not the case with financial liabilities in that CAS and IFRS have similar standards towards financial liabilities: financial liabilities that use fair value and affect profit and loss by their changes in fair value should use fair value measurement. There are also differences in non-financial assets and liabilities between CAS 39 and IFRS 13. For instance, initial measurement of fixed assets should apply fair value in both CAS 39 and IFRS 13. However, fixed assets cannot appreciate in CAS 39 while in IFRS 13 they can. In the measurement of fixed assets, IFRS 13 uses two types of measurement modes (cost and revaluation) while CAS 39 only applies the cost mode. Considering asset impairment, CAS 39 is virtually the same as IFRS, that is, fair value of an asset is the higher amount between the net amount of the asset's fair value without disposal expenses and the present value of the asset's future cash flow. Moreover, construction contract is not measurable in fair value in CAS 39 while in IFRS 13 it can.

In summary, there are still some differences between CAS 39 and IFRS 13. CAS 39 is neither as detailed as IFRS 13, nor as complete as IFRS 13 in terms of the integrity of fair value framework. Regardless of these differences, CAS 39 indicates that Chinese Accounting Standards on fair value measurement are in a steady progress of convergence towards IFRS 13. Then, a subsequent question arises, what are the market's reactions to this progress? We will employ an empirical methodology to examine stock market reactions to the emergency of CAS 39.

\section{Literature Review on Market Reactions}

The introduction of fair value standards usually cause significant market reactions in developed countries (Cornett et al. 1998; Bowen and Khan, 2009). What will happen in China as an emerging country?

In order to examine the market reactions to the introduction of fair value measurement standards, we use event study methods and decompose the topic into detailed research questions. 
The introduction of the 2006 edition CAS with the fair value measurement improved financial disclosure of Chinese companies in the capital market. According to Chinese Ministry of Finance (2011) ${ }^{5}$, from 2007 to 2010, the discrepancy rate of net income between using CAS and IFRS in Chinese $\mathrm{A}+\mathrm{H}^{6}$ dual listed companies decreased from $4.69 \%$ to $0.33 \%$; the discrepancy rate of the net asset decreased from $2.84 \%$ to $0.01 \%$. Gu (2015) studies value relevance of accounting information in Chinese listed companies before and after the 2006 edition CAS (from 2003 to 2011), and finds that the 2006 edition CAS improved value relevance of accounting information. Liu and Sun (2011) states that fair value measurement in the 2006 edition CAS improved information quality in financial reports of Chinese listed companies.

However, there are very different opinions on the introduction of fair value measurement in China. Han (2009) points out that after implementing the 2006 edition CAS with the fair value measurement, some listed companies made arbitrary judgments on fair value. Namely, listed companies applied different measurements within identical items or did not disclose the methods used to determine fair value in financial statements. Meanwhile, some researchers think that introducing and refining fair value measurement might cause risks in accounting supervision. For instance, Lv and $\mathrm{Li}$ (2014) consider that the complexity of fair value measurement and disclosure would lead to frauds or errors in listed companies, resulting in material misstatements in financial reports. With the high demand of professionalism and technicality in fair value measurement and disclosure, the 2006 edition CAS needs further improvements. In 2014, Chinese Ministry of Finance announced a revised version on fair value and its measurement, CAS 39.

Researchers also have different ideas on market reactions to the introduction of fair value measurement in financial reporting. Marcia et al. (1996) analyze abnormal returns on banking stocks, finding that fair value measurement has a better explanation on stock prices than historical cost information (book value). However, Robert et al. (2014) find that European investors in the banking sector have negative attitudes towards the introduction of fair value measurement related policies during the financial crisis. They also point out that the result does not indicate that the fair value measurement is as effective as historical cost. It is the measurement method of fair value accelerates the adjustment progress of asset price and source allocation, which influences the stability of the market. Palea (2014) holds a neutral view that historical cost method does not conflict with the fair value measurement because of the different functions these two methods serve. Historical cost informs investors of the cost of investment while the fair value measures the expected return on assets or liabilities. Sun (2011) studies market reactions on fair value-related proclamations during 2007 to 2008. He finds that investors positively address these proclamations. He also reveals that investors show responses to the disclosure of fair value information on listed companies, but information absorption usually lags. After analyzing market reactions to the first appearance of variable profit and loss of fair value in financial reports, $\mathrm{Li}$ and $\mathrm{Shi}$ (2008) also find that the fair value measurement has correlations with market movements. Tan et al. (2011) draw similar conclusions by applying event study. They find that the overreaction of the stock market significantly correlates to the variance of fair value, especially in financial industries. However, when concentrating on presentation position, Li et al. (2013) arrive at an opposite conclusion. They contend that the overreaction of the stock market correlates to presentation position rather than fair value measurement.

\section{Research Questions and Designs on Market Reactions}

This paper uses an event study methodology to examine market reactions to the international convergence of fair value measurement in China. In order to classify potentially different market reactions, we chose three events in the introductory process of fair value measurement in Chinese accounting standards: 1) the exposure of the draft new accounting standard of fair value measurement in 2012;2) the announcement of CAS 39 on January 2014; 3) the enforcement of CAS 39 on July 2014. In order to study the market reactions to the international convergence of fair value measurement standard in China, we formulate the following five research questions and we will test them afterwards:

Research question 1: How does stock market reaction to the exposure of the draft new fair value measurement standards in 2012? The draft new standards on fair value measurement help deliver more market relevant information in the financial statements of listed companies. It will help investors in making decisions. Therefore, we believe that investors welcome the draft new fair value accounting standards.

Research question 2: Does financial industries have more reactions than non-financial industries in the draft new fair value accounting standards in 2012? The applications of fair value measurement of financial assets and financial

\footnotetext{
${ }^{5}$ Accounting Department, Chinese Ministry of Finance. Analysis Report 2010 on Executing Enterprise Accounting Standards in Chinese Listed Companies [J]. Finance and Accounting for International Commerce, 2011(11): 13-27.

${ }^{6} \mathrm{~A}+\mathrm{H}$ indicates a company is listed in both A share market (the main board in either Shanghai Stock Exchange or Shenzhen Stock Exchange, using CAS) and Hong Kong Stock Exchange (using IFRS).
} 
liabilities are among the most important parts in the draft new fair value accounting standards. Financial assets and financial liabilities are among the most vital parts in financial institutions' business. Therefore, we predict that financial industries welcome the draft new fair value standards more than non-financial industries.

Research question 3: How does the market act towards the announcement of CAS 39 in January 2014? The official announcement of CAS 39 makes it a genuine accounting standard for fair value measurement. Based on similar reasons in the first research question, we think that market has positive reactions as well. There is a half-year period between the announcement and enforcement of CAS 39. We guess that investors may need time to absorb the possible implications of CAS 39. Even so, we still consider that market has significant reactions to the enforcement of CAS 39 in July 2014. Therefore, we come to the fourth research question.

Research question 4: How does the market react towards the implementation on CAS 39? Based on prior research questions $1 / 3 / 4$, the stock market has positive reactions to CAS 39 . However, the degrees of market reactions may be different. When the draft new fair value measurement standard was exposed, the market may have a limited level of reactions. The reason is that investors do not know whether or when the draft new standard could become a real standard. When the official CAS 39 announcement happened, the new standard came real, and then the market had the biggest reactions. As for the enforcement of CAS 39, investors already know the effective date and should have sufficient time to absorb the implications brought by CAS 39 in the stock market. Hence, the market has the smallest reactions compared to the preceding two events. Therefore, we have the fifth research question as follows:

Research question 5: Which one has higher market reactions, the announcement of CAS 39, the exposure of the draft new fair value measurement standard, or the enforcement of CAS 39 ?

Fama (1991) pointed out that "event studies can give a clear picture of the speed of adjustment of prices to information". This paper employs event study methodology to examine the implications to stock price changes through the events related to fair value measurement standards in China. We use event study methods in the following steps: define event and event period; obtain data samples; calculate abnormal returns; analyze the significance and directions of abnormal returns.

This study reviews three events that relate to the birth of CAS 39 based on previous analysis: Event A. On May 17th, 2012, Chinese Ministry of Finance exposed the draft new "Fair value measurement Standards"; Event B. On January 26th, 2014, Chinese Ministry of Finance announced CAS 39-Fair Value Measurement; Event C. On July 1st, 2014, CAS 39 came into effect.

There are usually three typical periods in event study methodology, shown in the figure below. Event period (T1-T2) includes the event date and the dates around the event date. For comparative reasons, we use 3 types of event periods in this paper: $[-1,0]$, which indicates market reactions in a super short term; $[-3,0]$ and $[-5,0]$, by which we examine the market reactions in advance. Here 0 is the event date, negative numbers represent dates before the event date, and positive numbers represent dates after the event date. We analyze results primarily by the event period $[-1,0]$ simply because it is a short-term period and not subject to the disturbance of other possible events in the period. The additional event periods $[-3,0]$ and $[-5,0]$ serve the purpose of the robust test. Estimation period (T0-T1) is a period used to estimate normal returns during event periods provided no such events happen. We choose 125 to 6 transactional days before event dates as the estimation period, namely $[-125,-6]$. There are 5 days before event dates not included in the estimation period to isolate estimation period and event period.

Estimation Period
Event Period
$\longrightarrow$

In order to calculate the abnormal returns in the events, we use the market model to estimate normal or expected returns. The equation is as follows:

Where

$$
R_{i t}=\alpha_{i}+\beta_{i} R_{m t}+\varepsilon_{i t}
$$

$R_{i t}$ is the actual return of stock $\mathrm{i}$ at time point $\mathrm{t}$,

$\alpha_{i}$ is a intercept item,

$\beta_{i}$ is the market beta of stock $i$,

$R_{m t}$ is the market return;

$\varepsilon_{i t}$ is an error term.

Abnormal returns are the differences between actual returns and normal or expected returns. We can estimate the parameters of the market model by using the time-series data in the estimation period. The equations of the model are as 
below:

$$
\begin{gathered}
A R_{i t}=R_{i t}-E\left(R_{i t}\right) \\
E\left(R_{i t}\right)=\widehat{\alpha}_{\iota}+\widehat{\beta}_{\iota} * R_{m t} \\
A R_{i t}=R_{i t}-\left(\widehat{\alpha}_{\iota}+\widehat{\beta}_{\iota} * R_{m t}\right)
\end{gathered}
$$

Cumulative abnormal returns (CAR) are the sum of abnormal returns in an event period. The equation of calculating CAR is as below:

\section{Data Sample and Descriptive Statistics}

$$
C A R_{i}=\sum A R_{i t}
$$

This paper chooses the main board stocks in both Shanghai and Shenzhen Stock Exchange. Referring to CSRC 2012 Industry Classification Standard, we separate these stocks into financial industries and non-financial industries due to their structural differences in the composition of assets and liabilities. We removed $\mathrm{ST}^{8}$ stocks, suspended stocks, delisted stocks and other defective samples. We also apply $1 \%$ and $99 \%$ winsorization on outliers in the data samples. All data in this study are RESSET financial database.

Table 4.1 exhibits the descriptive statistics of the sample for Event A, B and C. In Event A, the sample comprises of 41 stocks in financial industries in the event periods, and 2101 stocks in non-financial industries respectively. In Event B,

\begin{tabular}{|c|c|c|c|c|c|c|}
\hline Variables & Event & $\mathrm{N}$ & Mean & $\begin{array}{c}\text { Standard } \\
\text { Deviation }\end{array}$ & Maximum & Minimum \\
\hline \multicolumn{7}{|c|}{ Financial Industries } \\
\hline \multirow{3}{*}[-1,0]{ CAR } & $\mathrm{A}$ & 41 & $1.59 \%$ & 0.03 & $8.50 \%$ & $-1.55 \%$ \\
\hline & B & 43 & $-0.75 \%$ & 0.02 & $7.61 \%$ & $-6.52 \%$ \\
\hline & $\mathrm{C}$ & 45 & $-0.18 \%$ & 0.01 & $1.96 \%$ & $-1.54 \%$ \\
\hline \multirow[t]{3}{*}[-3,0]{$\mathrm{CAR}$} & A & 41 & $2.32 \%$ & 0.01 & $15.47 \%$ & $-2.94 \%$ \\
\hline & B & 43 & $-1.33 \%$ & 0.03 & $10.12 \%$ & $-9.18 \%$ \\
\hline & $\mathrm{C}$ & 45 & $-0.57 \%$ & 0.02 & $3.98 \%$ & $-5.28 \%$ \\
\hline \multirow[t]{3}{*}[-5,0]{ CAR } & A & 41 & $2.22 \%$ & 0.04 & $11.97 \%$ & $-3.28 \%$ \\
\hline & B & 43 & $-8.38 \%$ & 0.04 & $10.12 \%$ & $11.87 \%$ \\
\hline & $\mathrm{C}$ & 45 & $-0.77 \%$ & 0.02 & $4.46 \%$ & $-7.55 \%$ \\
\hline \multicolumn{7}{|c|}{ Non-financial Industries } \\
\hline \multirow[t]{3}{*}[-1,0]{ CAR } & $\mathrm{A}$ & 2101 & $0.27 \%$ & 0.03 & $21.41 \%$ & $-9.18 \%$ \\
\hline & B & 2267 & $4.74 \%$ & 0.04 & $20.85 \%$ & $-17.88 \%$ \\
\hline & $\mathrm{C}$ & 2189 & $0.20 \%$ & 0.03 & $19.33 \%$ & $-12.14 \%$ \\
\hline \multirow[t]{3}{*}[-3,0]{ CAR } & A & 2101 & $0.46 \%$ & 0.04 & $43.02 \%$ & $-18.82 \%$ \\
\hline & B & 2267 & $0.54 \%$ & 0.05 & $36.98 \%$ & $-35.39 \%$ \\
\hline & $\mathrm{C}$ & 2189 & $0.57 \%$ & 0.04 & $36.01 \%$ & $-22.52 \%$ \\
\hline \multirow[t]{3}{*}[-5,0]{$\mathrm{CAR}$} & A & 2101 & $0.89 \%$ & 0.05 & $55.18 \%$ & $-18.82 \%$ \\
\hline & B & 2267 & $0.82 \%$ & 0.06 & $51.41 \%$ & $-60.03 \%$ \\
\hline & $\mathrm{C}$ & 2189 & $0.49 \%$ & 0.05 & $55.73 \%$ & $-29.09 \%$ \\
\hline
\end{tabular}
the sample contains 43 stocks in financial industries and 2189 stocks in non-financial industries. In Event C, the sample covers 45 stocks in financial industries and 2189 stocks in non-financial industries respectively.

Table 4.1. Event A/B/C: Descriptive Statistics

Note: The $[-1,0]$ CAR indicates the Cumulative Abnormal Returns in event period $[-1,0]$, and so on. $\mathrm{N}$ means sample size in each event study. This table shows the sample size, mean cumulative abnormal returns, standard deviation, maximum and minimum cumulative abnormal returns in both financial and non-financial industries in each event period ([-1,0], $[-3,0],[-5,0])$ in each event (Event A, B and C).

\section{Empirical Results on Market Reactions}

We have three events that relate to the changes of fair value measurement standards. This section demonstrates and analyses the empirical test results of the three event studies.

Figure 5.1, Figure 5.2 and Figure 5.3 illustrate the abnormal returns around Event A, B and C. Table 5.1 and 5.2 shows the details of CAR in these three events. In terms of Event A, from Figure 5.1, we find that the stock market began to fluctuate significantly around the date of the Event. In other words, stock market clearly responded to Event A when Chinese Ministry of Finance exposed the draft new fair value measurement standards. We think that the choppy market reactions were due to the unfamiliarity of investors towards the draft new fair value measurement standard. In Event B,

7 CSRC: China Securities Regulatory Committee. CSRC 2012 standard on industry classification is currently the newest one.

${ }^{8}$ ST stocks: CSRC capped some stock name with a prefix ST or *ST to indicate that these stocks are Special Treatment stocks. ST stocks alert investors that these stocks have losses in past two years and may have the risk of being delisted. 
from Figure 5.2, we observe that abnormal returns became positive from negative since the 3rd day before the announcement of CAS 39 - Fair Value Measurement. However, abnormal returns became negative on the event day and then came to a stable increase. We consider that investors held positive attitudes towards the announcement of CAS 39. The abrupt decrease of abnormal returns may be that the announcement disturbed investors, and investors' reactions may become irrational in the period. After that, they began to take actions positively. In Figure 5.3 regarding to Event C, we see the abnormal return situation around the effective date of CAS 39. There is a similar trend to Event B from the 3rd day before the event date. Abnormal returns became slightly negative on the 2 nd day after the event and then increase to around zero. The stock market did response to Event C. Furthermore, when comparing the curves in Event $\mathrm{A} / \mathrm{B} / \mathrm{C}$, we can see that in Event $\mathrm{C}$, the market had the smallest fluctuation and the abnormal returns fluctuated near zero after the event date. We think that investors had absorbed information with respect to the new fair value measurement standard. This answers the research question 5 to some extent.

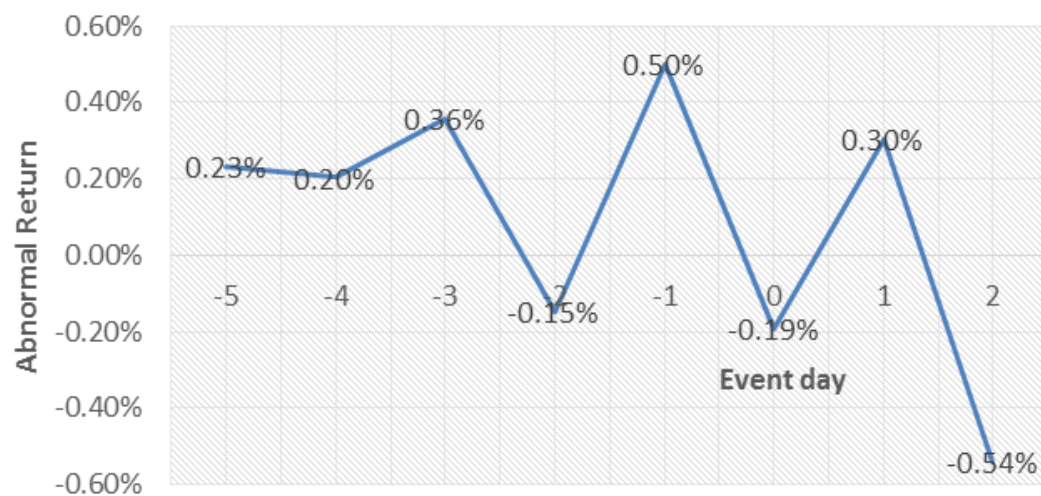

Figure 5.1. Abnormal Returns around Event A

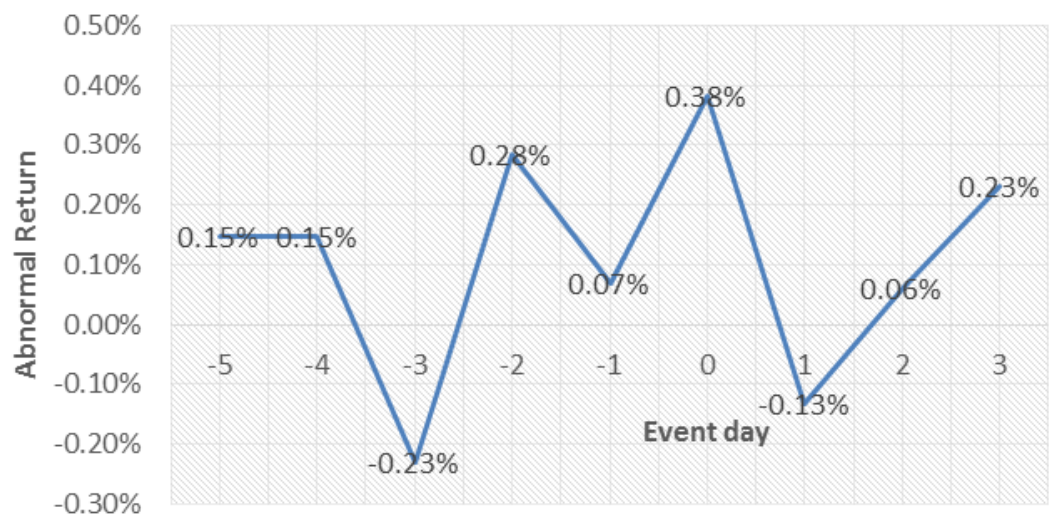

Figure 5.2. Abnormal Return around Event B

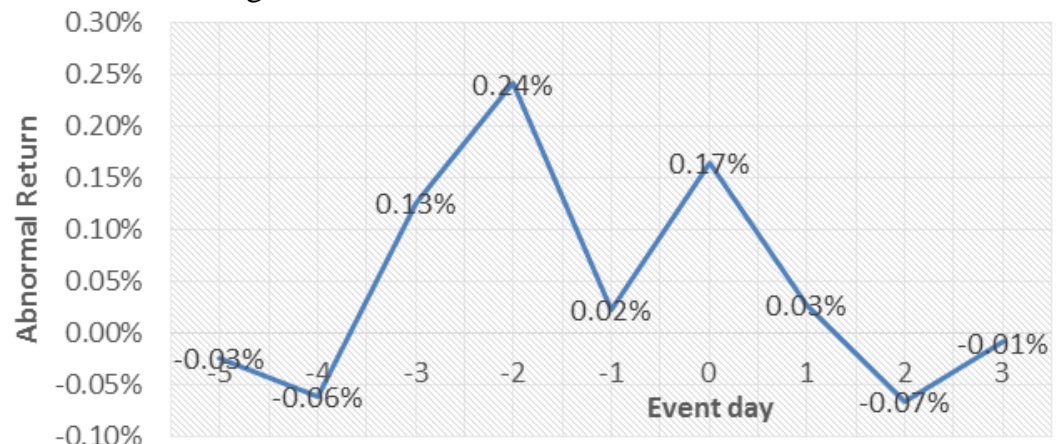

Figure 5.3. Abnormal Return around Event C

Table 5.1 shows overall CAR situations of Event A, B and C in three event periods $[-1,0],[-3,0]$, and $[-5,0]$ respectively. Table 5.2 shows Event CAR situations of Event A, B and C in financial and non-financial industries separately.

In Event A, Table 5.1 indicates that CARs in all event periods are significantly positive. The stock market welcomes the draft new fair value measurement standard. In Table 5.2, CARs of both financial and non-financial industries are all 
significantly positive in all the three event periods. Moreover, in event periods $[-1,0],[-3,0]$ and $[-5,0]$, CARs in financial industries are 5.88, 5.04, and 2.49 times of those in non-financial industries respectively. It shows that financial industries have much stronger reactions over non-financial industries towards the draft new fair value measurement standard. This responds to the research question 1 and 2. As Tan et al. (2011) contended, the overreaction of the market in financial industries was significantly correlated with the fair value measurement. Companies in financial industries often have more financial assets and financial liabilities than those in non-financial industries. It means that the fair value measurement standard has more influence on financial industries.

Table 5.1. Event A/B/C: CAR

\begin{tabular}{cccc}
\hline Event periods & Event & CAR & T Value \\
\hline$[-1,0]$ & A & $0.29 \%$ & $4.98 * * *$ \\
& B & $0.45 \%$ & $6.22 * * *$ \\
& C & $0.19 \%$ & $3.08 * * *$ \\
{$[-3,0]$} & A & $0.50 \%$ & $5.71 * * *$ \\
& B & $0.50 \%$ & $4.79 * * *$ \\
{$[-5,0]$} & C & $0.55 \%$ & $6.24 * * *$ \\
& A & $0.92 \%$ & $8.53 * * *$ \\
& B & $0.79 \%$ & $6.18 * * *$ \\
& C & $0.46 \%$ & $4.39 * * *$ \\
\hline
\end{tabular}

Note: $* * *$ denotes significance at the $1 \%$ level, $* *$ at $5 \%$, and $*$ at $10 \%$. This table shows the overall CARs in the three events.

Table 5.2. Event A/B/C: CAR in Financial and Non-financial Industries

\begin{tabular}{ccrr|rr}
\hline \multirow{2}{*}{ Event periods } & \multirow{2}{*}{ Event } & \multicolumn{2}{c}{ Financial Industries } & \multicolumn{2}{c}{ Non-financial Industries } \\
\cline { 3 - 6 } & & \multicolumn{1}{c}{ CAR } & T Value & \multicolumn{1}{c}{ CAR } & T Value \\
\hline$[-1,0]$ & $\mathrm{A}$ & $1.59 \%$ & $3.95 * * *$ & $0.27 \%$ & $4.50^{* * *}$ \\
& $\mathrm{~B}$ & $-0.75 \%$ & $-2.12^{* *}$ & $0.47 \%$ & $6.45^{* * *}$ \\
& $\mathrm{C}$ & $-0.18 \%$ & -1.63 & $0.20 \%$ & $3.15^{* * *}$ \\
{$[-3,0]$} & $\mathrm{A}$ & $2.32 \%$ & $3.41 * * *$ & $0.46 \%$ & $5.26 * * *$ \\
& $\mathrm{~B}$ & $-1.33 \%$ & $-2.72^{* * *}$ & $0.54 \%$ & $5.05^{* * *}$ \\
& $\mathrm{C}$ & $-0.57 \%$ & $-2.34 * *$ & $0.57 \%$ & $6.39 * *$ \\
{$[-5,0]$} & $\mathrm{A}$ & $2.22 \%$ & $3.42^{* * *}$ & $0.89 \%$ & $8.19^{* * *}$ \\
& $\mathrm{~B}$ & $-0.84 \%$ & -1.43 & $0.82 \%$ & $6.33^{* * *}$ \\
& $\mathrm{C}$ & $-0.77 \%$ & $-2.68 * *$ & $0.49 \%$ & $4.54 * * *$ \\
\hline
\end{tabular}

Note: *** denotes significance at the $1 \%$ level, ** at $5 \%$, and * at $10 \%$. This table contrasts the CARs in Event A, B and $\mathrm{C}$ in financial and non-financial industries.

From Table 5.1, CARs in Event B study of the entire market are significantly positive in all the three event periods. The overall market acts positively towards the announcement of CAS 39, which responds to the research question 3 . It also helps answer the research question 1 from an alternative point of view. However, in Table 5.2, CARs of Event B in financial industries acts negatively in event periods $[-1,0]$ and $[-3,0]$ while CARs in non-financial industries acts positively in all three event periods. This is different from investors' reactions to financial industries in Event A. We have no direct evidence to explain this situation. Nevertheless, we guess that it may have three reasons: 1) investors worry about the actual business performance of Chinese financial industries (e.g. bad debts in commercial loans). 2) CAS 39 has bigger influences on financial industries over non-financial industries. 3) The impression on the sub-prime loan crisis in the United States in 2008, where financial industries suffered heavily. The second reason appears to have a clue in Table 5.2. In Event B study, the absolute values of CAR in financial industries are all bigger than in non-financial industries (See Table 5.2, $0.75 \%>0.47 \%, 1.33 \%>0.54 \%$, and $0.84 \%>0.82$ ).

Table 5.1 also tells that the market as a whole has significantly positive reactions to Event $\mathrm{C}$ - the enforcement of CAS 39. This indicates that the stock market welcomes the enforcement of CAS 39. This responds to the research question 1 from another perspective. However, investors have different attitudes to financial and non-financial industries respectively. CARs in financial industries are all negative while they are all significantly positive in non-financial industries. This situation is very analogous to that in Event B. it seems to support our guess in explaining the results of Event B study. Except for event period [-1, 0], the absolute values of CAR in financial industries are either equal or bigger than those in non-financial industries $(0.57 \%=0.57 \%, 0.77 \%>0.49 \%$, and $0.15 \%>0.05 \%)$. We think that CAS 39 has more implications on financial industries over non-financial industries.

We aggregate the above results together in Table 5.3. It shows that, based on event period [-1, 0], CARs in Event B are the biggest, CARs in Event A are next, and CARs in Event $\mathrm{C}$ are the smallest. This indicates that market has the biggest reaction to the announcement event of CAS 39, the second biggest reaction to the exposure of the draft new fair value standard, and smallest reaction to the implementation of CAS 39. This answers the research question 5. Although event periods $[-3,0]$ and $[-5,0]$ does not support this sequence of reaction levels, we still tend to hold this result. The reason is 
that event period $[-1,0]$ is the shortest event period, which is less possibly disturbed or contaminated by other unobservable events compared to the other two event periods $[-3,0]$ and $[-5,0]$.

Table 5.3. Comparison of CARs in Event A/B/C

\begin{tabular}{cccc}
\hline Event periods & CAR in Event A & CAR in Event B & CAR in Event C \\
\hline$[-1,0]$ & $0.29 \%$ & $0.45 \%$ & $0.19 \%$ \\
{$[-3,0]$} & $0.50 \%$ & $0.50 \%$ & $0.55 \%$ \\
{$[-5,0]$} & $0.92 \%$ & $0.79 \%$ & $0.46 \%$ \\
\hline
\end{tabular}

Note: This table compares the overall CARs in Event A, B and C in each event period.

\section{Conclusions}

In the move towards IFRS around the globe, introduction of a systematic fair value measurement standard became a significant change in Chinese accounting standards. This paper firstly compares Chinese accounting standard on fair value measurement, CAS 39 with international accounting standard on fair value measurement, IFRS 13. Among 53 clauses in CAS 39, 41 clauses or $77.36 \%$ are consistent with IFRS 13, 11 clauses or $20.75 \%$ are basically consistent with IFRS 13. This indicates that $98.11 \%$ of clauses in CAS 39 are either consistent or basically consistent with IFRS 13. Therefore, Chinese fair value measurement standards are on the way of international convergence with IFRS. However, we also find that there are further jobs for Chinese accounting standard makers to do in terms of international convergence in fair value measurement standards: 1) IFRS 13 has 103 clauses and appendix items in specifying the rules on fair value measurement while CAS 39 only has 53 clauses. Compared to CAS 39, IFRS 13 has much more details, examples, and clearer explanations on applicable and unsuitable situations; 2 ) from the perspective of fair value measurement integrity of framework, IFRS 13 is more integrated than CAS 39. In summary, we think that CAS 39 needs more steps to catch up with IFRS 13 on the way of international convergence.

Aside from differences from IFRS 13, the study provides evidence on the economic consequences of introducing fair value measurement in firms. From market responses towards CAS 39, we find that Chinese stock market has significantly positive reactions to birth events of CAS 39, including the draft version exposure of new fair value measurement standard in 2012, the announcement of CAS 39 and the enforcement of CAS 39. The Chinese stock market warmly welcomes CAS 39. Consequently, the responses reflect indirectly that the market generally welcomes the international convergence of fair value measurement standards.

However, the stock market has sophisticated or even contradicted attitudes to the implications of CAS 39 on financial industries and non-financial industries. Stock market consistently supports the application of CAS 39 in non-financial industries from the draft exposure of new fair value measurement standard to the enforcement of CAS 39. However, the market has contradicted attitudes to the application of CAS 39. When Chinese Ministry of Finance exposed the draft new version of the fair value measurement standard, the market holds positive expectation to its application in financial industries. Nevertheless, in the subsequent events of announcement and enforcement of CAS 39, market behaves negative responses towards its application in financial industries. This seems to reveal that investors worry about the influences of CAS 39 in financial industries. In other words, investors think that the applications of CAS 39 or the international convergence of fair value measurement accounting standards may benefit non-financial industries but hurt financial industries. Although we do not have direct evidence in this paper, we guess that there may be some weakness in Chinese financial industries to make it in an unfavorable situation in the international convergence of fair value measurement accounting standard.

Investors' attitudes towards the application of CAS 39 not only vary in the directions of reactions between financial industries and non-financial industries, but also in the levels of strength in reactions. We find that, in general, the market usually has more intensive or bigger strength of reactions in financial industries than in non-financial industries. The reason may be that financial industries have more financial assets and financial liabilities that are more subject to the influences of international convergence of fair value measurement accounting standard.

Besides, we also find an interesting phenomenon that prior literatures barely mention. The market has the strongest reaction to the announcement of the new fair value measurement standard, the second strongest reaction to the exposure of the draft new fair value measurement standard and smallest response to the enforcement of the new standard.

We hope that our results in this paper could help the future development of Chinese fair value measurement accounting standard towards international convergence.

\section{References}

Bowen, R. M., \& Khan, U. (2014). Market reactions to policy deliberations on fair value accounting and impairment rules during the financial crisis of 2008-2009. Journal of Accounting \& Public Policy, 33(3), 233-259. https://doi.org/10.1016/j.jaccpubpol.2014.02.003

Cornett, M. M., Rezaee, Z., \& Tehranian, H. (1996). An investigation of capital market reactions to pronouncements on 
fair value accounting. Journal of Accounting \& Economics, 22(s1-3), 119-154.

https://doi.org/10.1016/S0165-4101(96)00440-5

Fama, E. (1991). Efficient capital markets: II. Journal of Finance, 46(46), 1575-1617. https://doi.org/10.1111/j.1540-6261.1991.tb04636.x

$\mathrm{Gu}, \mathrm{S}$. (2015). A study on the implications of IFRS convergence in accounting standards to accounting information quality - Empirical test of value relevance based on b-s components. Communication of Finance and Accounting, 9 , $10-13$.

Han, W. (2009). The black hole effect of fair value in financial industries-Apocalypse from subprime crisis in the United States. Finance and Accounting Monthly, 5, 5-7.

Li, X., \& Shi, F. (2008). Market effect analysis on the changes of fair value in financial and insurance industries. Science-Technology and Management, 10(6), 62-64.

Li, Z., Li, H., \& Lian, Y. (2013). Market reactions to the listed changes of fair value - Empirical evidence from Chinese listed companies. Accounting Research, 10, 13-19+96.

Liu, Y., \& Sun, S. (2011). The value relevance of fair value information in Chinese listed companies - An empirical study based on the international convergence of enterprise accounting standards. Accounting Research, 2, 16-22.

Lv, X., \& Li, Y. (2014). Construction of accounting regulatory system - Based on enterprise accounting standard no.39 Fair value measurement. Journal of Jiangxi University of Finance and Economics, 6, 55-61.

Palea, V. (2014). Fair value accounting and its usefulness to financial statement users. Journal of Financial Reporting and Accounting, 12(2), 102-116. https://doi.org/10.1108/JFRA-04-2013-0021

Sun, S. (2011). Market reactions of fair value information - Empirical study based on international convergence of enterprise accounting standards. Research on Financial and Economic Issues, 1, 116-123.

Tan, H, Cai, L, \& Cai, C. (2011). Fair value accounting and the overreaction of the stock returns - Evidence from the security market in China. Economic Research Journal, 7, 130-143.

\section{Copyrights}

Copyright for this article is retained by the author(s), with first publication rights granted to the journal.

This is an open-access article distributed under the terms and conditions of the Creative Commons Attribution license which permits unrestricted use, distribution, and reproduction in any medium, provided the original work is properly cited. 